\title{
Morphological characterization of seeds and germination of Pseudotsuga menziesii (Mirb.) Franco (Pinaceae)
}

\section{Caracterización morfológica de semillas y germinación de Pseudotsuga menziesii (Mirb.) Franco (Pinaceae)}

RÍOS-PALMA, Nedvy ${ }^{1 \dagger}$, CONTRERAS-TOLEDO, Aremi Rebeca ${ }^{2 *}$, PICHARDO-GONZÁLEZ, Juan Manuel $^{2}$ and RASCÓN-AYALA, Jesús Manuel ${ }^{1}$

\author{
${ }^{1}$ Universidad Tecnológica de la Tarahumara. Carretera Guachochi-Yokivo Km. 1.5, Colonia Turuseachi, Cd. Guachochi, \\ Chihuahua. C.P. 33180 \\ ${ }^{2}$ Centro Nacional de Recursos Genéticos - Instituto Nacional de Investigaciones Forestales, Agrícolas y Pecuarias. Boulevard \\ de la Biodiversidad No. 400. Rancho las Cruces, Tepatitlán de Morelos, Jalisco. C.P. 47600
}

ID 1 ${ }^{\text {st }}$ Author: Nedvy Ríos-Palma / ORC ID: 0000-0002-3070-6480, CVU CONACYT ID: 1015984

ID $1^{\text {st }}$ Coauthor: Aremi R. Contreras-Toledo / ORC ID: 0000-0003-3526-8843, Researcher ID Thomson: X-2274-2019, CVU CONACYT ID: 221547

ID $2^{\text {nd }}$ Coauthor: Juan M. Pichardo-González / ORC ID: 0000-0003-2281-3101, Researcher ID Thomson: W-2141-2018, CVU CONACYT ID: 44748

ID $3^{\text {rd }}$ Coauthor: Jesús M. Rascón-Ayala / ORC ID: 0000-0003-0201-4417, CVU CONACYT ID: 779835

DOI: $10.35429 /$ JNAS.2019.18.6.24.30

Received March 21, 2019; Accepted June 30, 2019

\begin{abstract}
Pseudotsuga menziesii (Mirb.) Franco is a species of economic and ecological importance for Mexico. Several actions have been implemented for its ex situ conservation. However, the lack of characterization data is a limiting factor in genebanks. In this study, morphological characteristics and seed germination traits were evaluated in 12 accessions of $P$. menziesii from Tlaxcala and Puebla. Fifteen seed variables, germination percentage (PG), days to germination (DG) and radicle growth (CR) were measured in 100 seeds (four replicas of 25 seeds each) per accession. A principal component analysis, a cluster analysis and the estimation of the relationship between seed variables and germination traits were performed. The variables that had largest influence on the distribution of morphological variation were: LA, ASC, $\mathrm{AS}$ and AA/AS. The accessions were distributed in five general groups according mainly to their geographical origin. For some accessions, PG and CR had a direct relationship with seed size variables. These results showed the presence of variation and the influence of seed morphology on the germination of the evaluated accessions.
\end{abstract}

Pseudotsuga menziesii, Diversity, Conservation

\begin{abstract}
Resumen
Pseudotsuga menziesii (Mirb.) Franco es una especie de importancia ecológica y económica para México. Diversas acciones se están llevando a cabo para su conservación ex situ. Sin embargo, una de las principales limitantes en los bancos de germoplasma es la falta de datos de caracterización. En este estudio se evaluaron las características morfológicas de semilla y germinación de 12 accesiones de $P$. menziesii provenientes de Tlaxcala y Puebla. Se registraron 15 variables de semilla, además del porcentaje de germinación (PG), días a germinación (DG) y crecimiento radicular (CR) en 100 semillas (cuatro repeticiones de 25 semillas) de cada accesión. Se realizó un análisis de componentes principales, un análisis de agrupamientos y se estimaron las relaciones entre variables de semilla y germinación. Se observó que las características que más influyen en la variación morfológica son: LA, ASC, AS y AA/AS. Las accesiones se distribuyeron en cinco grupos que concuerdan principalmente con su origen geográfico. También se observó que, para algunas accesiones, las variables PG y CR estuvieron directamente relacionadas al tamaño de la semilla. Los resultados indicaron la existencia de variación y la influencia de la morfología de las semillas sobre la germinación de las accesiones evaluadas.
\end{abstract}

Pseudotsuga menziesii, Diversidad, Conservación

Citation: RÍOS-PALMA, Nedvy, CONTRERAS-TOLEDO, Aremi Rebeca, PICHARDO-GONZÁLEZ, Juan Manuel and RASCÓN-AYALA, Jesús Manuel. Morphological characterization of seeds and germination of Pseudotsuga menziesii (Mirb.) Franco (Pinaceae). Journal of Natural and Agricultural Sciences. 2019, 6-18: 24-30

\footnotetext{
*Correspondence to Author (contreras.aremi@inifap.gob.mx)

$\dagger$ Researcher contributing first author
} 


\section{Introduction}

Pseudotsuga menziesii (Mirb.) Franco is a perennifolia species up to $20 \mathrm{~m}$ tall (Conafor, 2018), timber (Sanhueza et al., 1998) and highly demanded as an ornamental plant (Álvarez et al., 2007). This species is native to the American continent, distributed from British Columbia in Canada to the mountains of southern Mexico (CONAFOR, 2018). In Mexico it is naturally distributed mainly in the northern portion of the Sierra Madre Occidental, in the states of Chihuahua, Coahuila, Durango, Guerrero, Hidalgo, State of Mexico, Nuevo León, Oaxaca, Puebla, Querétaro, San Luis Potosí, Sinaloa, Sonora, Tamaulipas, Tlaxcala, Veracruz and Zacatecas (Villaseñor, 2016; CONAFOR, 2018).

In Mexico, many of the natural populations of this genus are subject to strong anthropogenic pressures, especially those located on the border of the agricultural frontier or in areas of logging (timber or other), so there is a high risk of degradation and loss of genetic diversity (Reyes et al., 2005). P. menziesii is classified as of Minor Concern (LC) under the IUCN Red List of Threatened Species (Farjon, 2013), however, P. menziesii var. Glauca is listed as under special protection (DOF, 2015). The structure and levels of genetic diversity of Mexican populations of $\mathrm{P}$. menziesii is still unknown. Some studies suggest the prevalence of reduced sizes, a restricted distribution of populations and other factors that increase inbreeding (Montiel Castelán et al., 2019) and reduced level of diversity, especially in populations in the central region of Mexico (Cruz- Nicolás et al., 2011). This is related to the reduction in seed production, germination problems and initial growth (Ventura Ríos et al., 2010).

Significant conservation and characterization efforts have been carried out for the conservation of this and other species, an example of this is the establishment of the National Collection of Forest Genetic Resources, carried out by the CNRG-INIFAPCONAFOR (Pichardo et al., 2018). The collection includes 406 accessions of $P$. mensiezii, from the states of Chihuahua, Coahuila, Durango, Puebla, Querétaro and Tlaxcala.
The generation of information on the morphological characteristics of the materials preserved in the germplasm bank of the CNRG, will allow to develop more effective conservation strategies, evaluate genetic diversity and determine levels of genetic erosion as well as facilitate access and availability of these forest genetic resources (RGF).

Therefore, the objective of this work was to evaluate the morphological diversity and germination of accessions of $\mathrm{P}$. menziesii that will be conserved in the long term in the CNRGINIFAP.

\section{Materials and methods}

\section{Vegetal material}

Twelve accessions of P. menziesii entered into the CNRG in 2018 were evaluated as part of the National Collection of Forest Genetic Resources, from four locations within the natural range of the species. Seven of these accessions were from Terrenate, Tlaxcala $\left(19^{\circ} 28^{\prime} 31.8\right.$ "N, $\left.977^{\circ} 55^{\prime 2} 25.8^{\prime \prime} \mathrm{W}\right)$, three from Cuatexmola, Puebla $\left(19^{\circ} 30^{\prime} 10.7\right.$ "N, $\left.97^{\circ} 49^{\prime} 43.7^{\prime \prime} \mathrm{W}\right)$, one from La Caldera, Puebla $\left(19^{\circ} 29 \cdot 57.7\right.$ "N, $97^{\circ}$ $\left.52^{\prime} 12.7^{\prime \prime} \mathrm{W}\right)$ and one from Tlachichuca, Puebla $\left(19^{\circ} 06^{\prime} 46.8\right.$ "N, $\left.97^{\circ} 25^{\prime} 06.7^{\prime \prime} \mathrm{W}\right)$.

\section{Measurement of morphological variables}

15 variables were recorded in 100 seeds of each accession (four repetitions of 25 seeds each), related to size and shape: Complete seed area (ASC), Complete seed perimeter (PSC), Wing length (LA), Width Wing (AA), Wing Appendix Length (LAA), Seed Length (LS), Seed Width (AS), Seed Thickness (GS), Wing Length / Wing Width (LA / AA), Length Wing / Seed Length (LA / LS), Wing Appendix Length / Seed Length (LAA / LS), Wing Width / Seed Width (AA / AS), Seed Length / Seed Width (LS / AS), Seed length / Seed thickness (LS / GS), Seed width / Seed thickness (AS / GS). The seeds were digitized on Epson ${ }^{\circledR}$ Perfection V750 PRO scanner and measurements were taken using ImageJ software v.1.52a (Ferreira and Rasband, 2018).

\section{Germination}

After the morphological characterization, the germination of the same 100 seeds was carried out, placing each repetition of 25 seeds on a roll of filter paper. 
The rolls were kept in the germination room at a temperature between 25 and $27^{\circ} \mathrm{C}$, with a relative humidity of $80 \pm 5 \%$ and with a photoperiod equivalent to 16 hours of light and 8 hours of darkness. Irrigation was carried out periodically with distilled water and the phytosanitary control consisted of Captan ${ }^{\circledR}$ applications at a concentration of $2 \%$. Finally, three variables were recorded: Germination percentage (PG) expressed as the percentage of seeds that germinated in relation to the percentage of seeds sown; Days to germination (DG) measured as the average number of days from sowing to germination, and Root growth (CR) measured on the fourth day after germination.

\section{Statistic analysis}

From the standardized matrix of variable data, a correlation analysis was performed as the basis for the analysis of main components (ACP) to identify the most important variables in the differentiation of accessions. Cluster analysis was also performed using genetic distance and the Unweighted Pair Group Method with Arithmetic Mean (UPGMA) clustering method to define similarity relationships. These analyzes were carried out in NTSYSpc v.2.1 (Rohlf, 2008). Finally, the relationships between seed variables and germination parameters were analyzed.

\section{Results and Discussion}

The results obtained from the seed morphological variables are synthesized in Table 1. The ACP shows that the first three components meet $86.47 \%$ of the total variability in the accessions (Table 2). The first main component (CP1) accumulates $49.18 \%$ of said variability, while the second $(\mathrm{CP} 2)$ and third component (CP3) collect 23.42\%, $13.86 \%$, respectively. The variables that contributed most to CP1 were LA, LAA, AS, LA / LS, LAA / LS, AA / AS and ASC (Table 3). Likewise, the variables that contributed the most in $\mathrm{CP} 2$ were AA and LS, while the GS and LS / GS were the variables that most influenced CP3. The projection of the accessions in the first two components (Figure 1) allows to appreciate the separation of the accessions by their place of origin. A first group is observed in quadrant I composed of accessions from the state of Puebla. On the other hand, accessions from the state of Tlaxcala showed greater differentiation between quadrants II, III and IV.

ECORFAN@ All rights reserved
Cluster analysis generated similar groupings (Figure 2), suggesting congruence between accessions. In general, five groups can be observed. Groups I, II and II were made up of accessions from the state of Tlaxcala while groups IV and V concentrated the accessions of Puebla. However, there is a greater distance from the accessions of groups I and II to the rest of the groups, which suggests a greater differentiation of these accessions. These results point to the existence of a wide variability in the evaluated accessions. Similar results were reported in other species.

The morphological variables and the physical characteristics analyzed of the seed in Taxus globosa Schltdl. allowed to establish significant differences between geographical regions (Ramírez-Sánchez et al., 2011). Miniño Mejía et al. (2014) analyzed the variability between populations of Pinus occidentalis Swartz based on morphological characteristics of the seed, while the external characteristics of the seeds allowed to identify different levels of variation in Bombacopsis quinata (Jacq.) Dugand and Anacardium excelsum (Bertero \& Balb ex Kunth) Skeels (Espitia Camacho et al., 2017). In addition, the variation in the morphological characteristics of the fruit, seed and seedling of Chrysophyllum rufum Mart., Contributed to the identification and delimitation of the species in its natural habitat (Lima et al., 2017). Thus, phenotypic variability has been observed in P. menziesii with a different one based on the morphological characteristics of the cones (Chekmeneva et al., 2019).

\begin{tabular}{|l|r|r|r|r|r|}
\hline Variable & \multicolumn{1}{c}{ Mean } & $\begin{array}{l}\text { Standard } \\
\text { deviation }\end{array}$ & \multicolumn{1}{c|}{ Min } & \multicolumn{1}{c|}{ Max } \\
\hline LA & 7.3814 & 0.9979 & 12 & 5.5477 & 8.4539 \\
\hline AA & 4.9936 & 0.3851 & 12 & 4.1819 & 5.4714 \\
\hline LAA & 2.0979 & 0.2634 & 12 & 1.4624 & 2.3605 \\
\hline LS & 6.1886 & 0.3472 & 12 & 5.8518 & 6.8083 \\
\hline AS & 3.0577 & 0.2124 & 12 & 2.6110 & 3.4323 \\
\hline GS & 1.6427 & 0.0925 & 12 & 1.4790 & 1.8742 \\
\hline LA/AA & 1.4887 & 0.1884 & 12 & 1.1453 & 1.7204 \\
\hline LA/LS & 1.2126 & 0.1973 & 12 & 0.8466 & 1.4469 \\
\hline LAA/LS & 0.3444 & 0.0453 & 12 & 0.2421 & 0.3985 \\
\hline AA/AS & 1.6592 & 0.1771 & 12 & 1.3250 & 1.9590 \\
\hline LS/AS & 2.0473 & 0.0958 & 12 & 1.9314 & 2.2615 \\
\hline LS/GS & 3.8082 & 0.1989 & 12 & 3.5457 & 4.1935 \\
\hline AS/GS & 1.8772 & 0.0872 & 12 & 1.7035 & 2.0124 \\
\hline ASC & 44.6781 & 5.4209 & 12 & 33.7350 & 50.3315 \\
\hline PSC & 34.1821 & 2.6796 & 12 & 30.4680 & 39.5991 \\
\hline
\end{tabular}

Table 1 Mean, standard deviation and minimum and maximum values of 15 morphological variables of $\mathrm{P}$. menziesii seed 


\begin{tabular}{|l|r|r|r|}
\hline MC & Own values & Percentage & Cumulative \\
\hline 1 & 7.37743858 & 49.1829 & 49.1829 \\
\hline 2 & 3.51369025 & 23.4246 & 72.6075 \\
\hline 3 & 2.07926858 & 13.8618 & 86.4693 \\
\hline 4 & 0.97225922 & 6.4817 & 92.9510 \\
\hline 5 & 0.71649193 & 4.7766 & 97.7277 \\
\hline 6 & 0.26725162 & 1.7817 & 99.5093 \\
\hline 7 & 0.06500038 & 0.4333 & 99.9427 \\
\hline 8 & 0.00526606 & 0.0351 & 99.9778 \\
\hline 9 & 0.00256491 & 0.0171 & 99.9949 \\
\hline 10 & 0.00066862 & 0.0045 & 99.9993 \\
\hline
\end{tabular}

Table 2 Own values and proportion of variance explained by the first ten main components (MC) generated by 15 morphological seed variables in 12 accessions of $\mathrm{P}$. menziesii.

\begin{tabular}{|l|r|r|r|}
\hline Own vectors & \multicolumn{1}{c|}{ CP1 } & \multicolumn{1}{c|}{ CP2 } & \multicolumn{1}{c|}{ CP3 } \\
\hline LA & $\mathbf{0 . 9 1 1 7}$ & 0.1982 & 0.0616 \\
\hline AA & 0.5563 & $\mathbf{- 0 . 7 9 3 8}$ & -0.0370 \\
\hline LAA & $\mathbf{0 . 7 0 4 7}$ & -0.6366 & -0.1930 \\
\hline LS & -0.4816 & $\mathbf{- 0 . 8 0 1 9}$ & 0.0704 \\
\hline AS & $\mathbf{- 0 . 8 2 3 0}$ & -0.4529 & -0.1653 \\
\hline GS & -0.6120 & -0.3161 & -0.6840 \\
\hline LA/AA & 0.6316 & 0.6856 & 0.0974 \\
\hline LA/LS & $\mathbf{0 . 8 9 0 0}$ & 0.3943 & -0.0279 \\
\hline LAA/LS & $\mathbf{0 . 8 3 3 1}$ & -0.3175 & -0.2873 \\
\hline AA/AS & $\mathbf{0 . 9 2 9 2}$ & -0.2796 & 0.0823 \\
\hline LS/AS & 0.6300 & -0.2814 & 0.3547 \\
\hline LS/GS & 0.1478 & -0.5540 & $\mathbf{0 . 7 9 7 2}$ \\
\hline AS/GS & -0.5012 & -0.3400 & 0.5624 \\
\hline ASC & $\mathbf{0 . 9 2 0 4}$ & -0.3065 & -0.1037 \\
\hline PSC & 0.4370 & -0.3011 & -0.5905 \\
\hline
\end{tabular}

Table 3 Own vectors of the first three main components (MC) generated by 15 seed morphological variables in 12 accessions of P. menziesii.

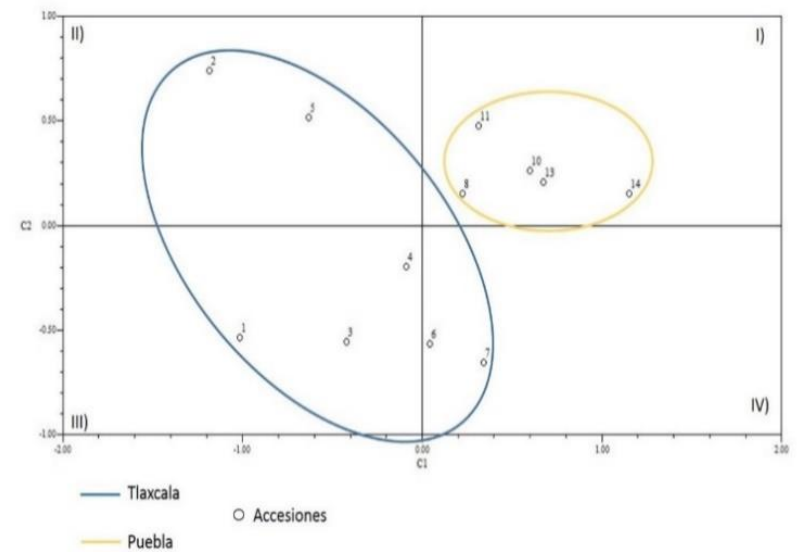

Figure 1 Distribution of the 12 accessions of P. menziesii in the first two main components (CP1 and CP2) derived from 15 seed morphological variables

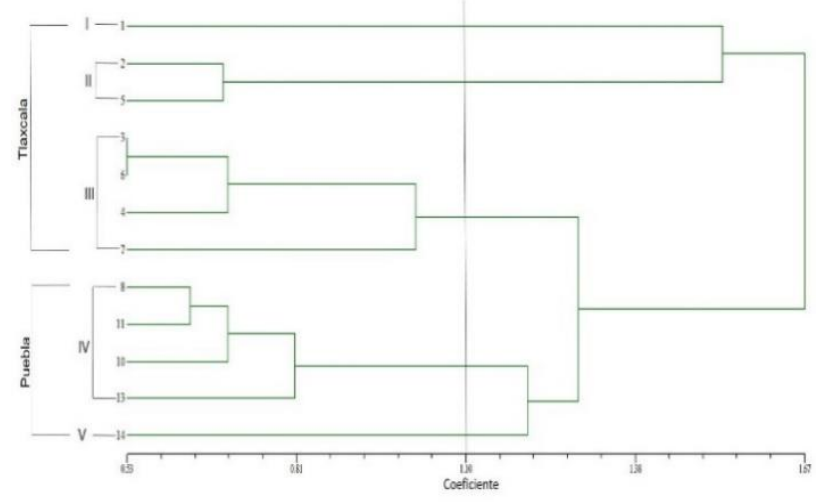

Figure 2 Grouping of the 12 accessions of P. menziesii based on 15 seed morphological variables, based on genetic distance and using the UPGMA method

The germination percentage varied from 41 to $92 \%$ (Table 4). On average, accessions from the state of Tlaxcala presented a germination of $69.3 \%$, while for accessions from the state of Puebla it was $72.8 \%$. Germination days varied from 7.13 to 8.25 , with an average of 7.8 DG for accessions coming from Tlaxcala and 7.7 for accessions from Puebla. On the other hand, a variation in root growth of 16 to $23 \mathrm{~mm}$ was observed, with an average of 18.5 and 18.9 for accessions coming from Tlaxcala and Puebla, respectively.

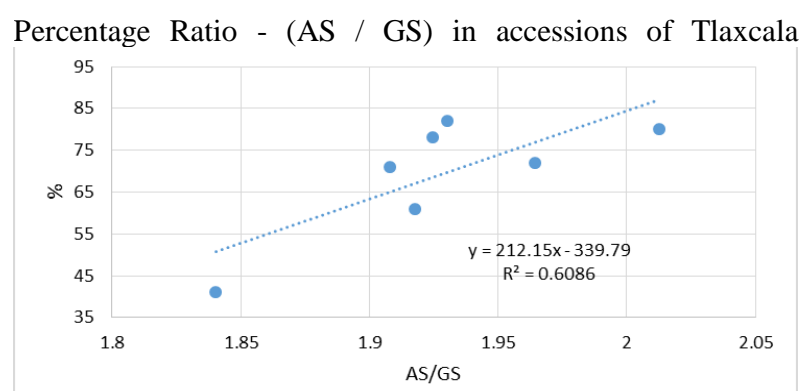

Percentage Ratio - (LS / AS) in accessions of Puebla

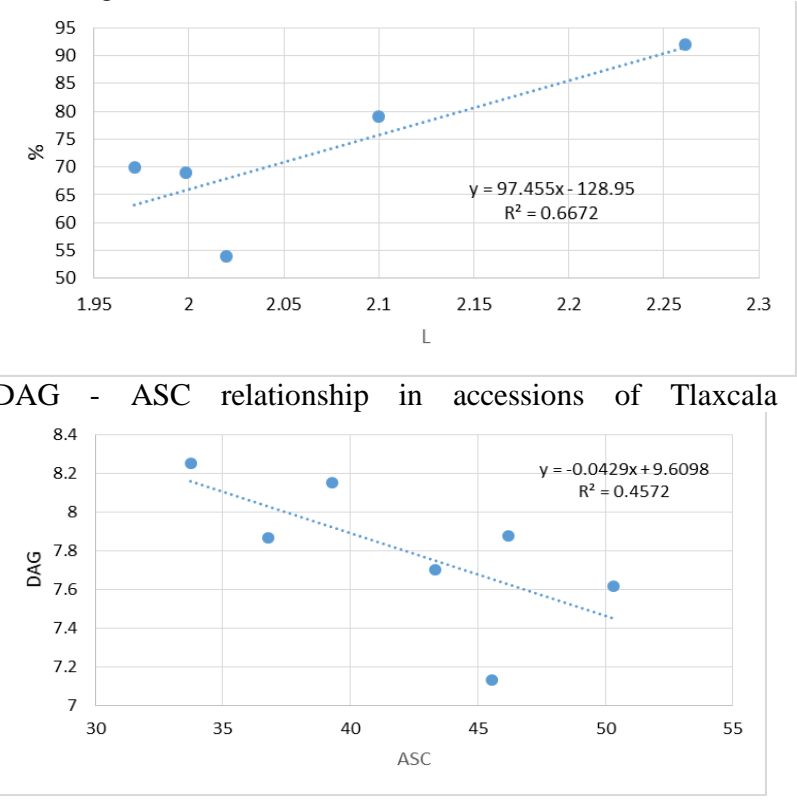

RÍOS-PALMA, Nedvy, CONTRERAS-TOLEDO, Aremi Rebeca, PICHARDOGONZÁLEZ, Juan Manuel and RASCÓN-AYALA, Jesús Manuel. Morphological characterization of seeds and germination of Pseudotsuga menziesii (Mirb.) Franco characterization of seeds and germination of Pseudotsuga menziesi
(Pinaceae). Journal of Natural and Agricultural Sciences. 2019 


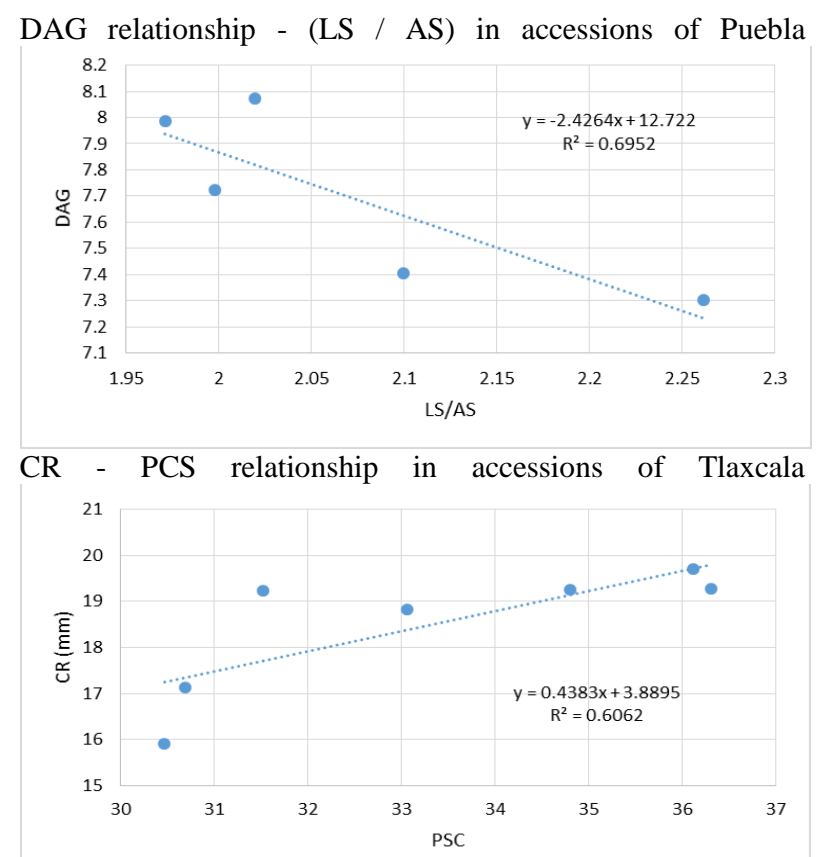

Relationship CR - (LS / GS) in accessions of Puebla 25

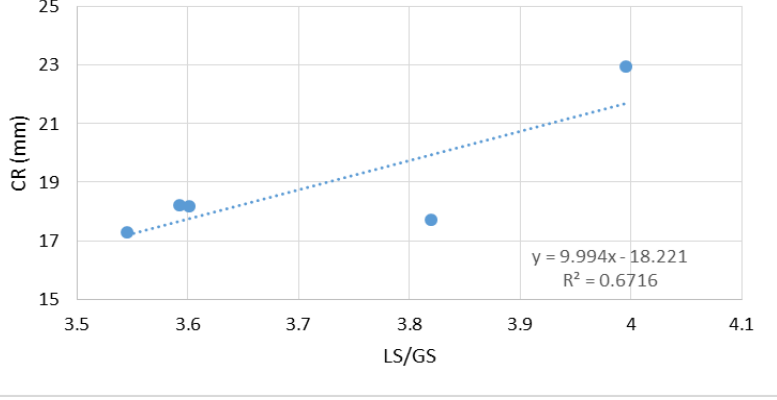

Figure 3 Germination percentage ratio (PG) with A) Seed width / Seed thickness (AS / GS) and B) Seed length / Seed width (LS / AS). Relationship of Days to Germination (DG) with C) Complete Seed Area (ASC) and D) Seed Length / Seed Width (LS / AS). Root Growth Ratio (CR) with E) Full Seed Perimeter (PSC) and F) Seed Length / Seed Thickness (LS / GS).

\begin{tabular}{|l|l|r|r|c|}
\hline \multicolumn{1}{c}{ Location } & Accession & PG & DG & CR \\
\hline Terrenate, Tlaxcala & 1 & 41 & 8.15 & 19.26 \\
\hline Terrenate, Tlaxcala & 2 & 71 & 8.25 & 17.14 \\
\hline Terrenate, Tlaxcala & 3 & 72 & 7.70 & 19.24 \\
\hline Terrenate, Tlaxcala & 4 & 80 & 7.88 & 18.82 \\
\hline Terrenate, Tlaxcala & 5 & 61 & 7.87 & 15.91 \\
\hline Terrenate, Tlaxcala & 6 & 82 & 7.13 & 19.25 \\
\hline Terrenate, Tlaxcala & 7 & 78 & 7.62 & 19.71 \\
\hline La Caldera, Puebla & 8 & 54 & 8.07 & 17.70 \\
\hline Cuatexmola, Puebla & 10 & 69 & 7.72 & 18.21 \\
\hline Cuatexmola, Puebla & 11 & 70 & 7.99 & 18.17 \\
\hline Cuatexmola, Puebla & 13 & 79 & 7.41 & 17.27 \\
\hline Tlachichuca, Puebla & 14 & 92 & 7.30 & 22.98 \\
\hline
\end{tabular}

Table 4 Germination percentage values (PG), days to germination (DG) and root growth (CR) in accessions of P. menziesii

The results allowed establishing relationships between morphological characteristics and germination variables.
For example, a directly proportional trend was observed between the relationship of PG with the variables AS / GS and LS / AS with $\mathrm{R}^{2}$ of 0.6086 and 0.6672 , respectively, as well as between CR and the variables PSC and LS / GS, with R2 of 0.6062 and 0.6716 . On the other hand, a negative relationship between DG with ASC and LS / AS was observed, with $\mathrm{R}^{2}$ of 0.4572 and 0.6952 , respectively.

These data suggest that, in general, the size of the seed is directly related to the analyzed variables of the germination of P. menziesii, that is to say, the larger the size of the seed, the germination not only increases, but it also has greater root growth. . Bonfil (1998) conducted an investigation with two Quercus species and observed that the size of the seed had a direct effect on survival, suggesting that the size of the seed correlates directly with the germination and growth of plants in some species forestry However, the regenerative capacity in natural ecosystems is also determined by a greater number of biotic and abiotic factors (Chekmeneva et al., 2019; Peters and Visscher, 2019). On the other hand, seeds with high germination rates can contribute to the development of natural forest management and regeneration plans (Jaouadi et al., 2019).

\section{Conclusions}

The previous results allowed establishing differences in the size and shape between the accessions, identifying a wide morphological diversity of the seeds. Likewise, the data indicated the influence of the morphology of the seeds on the germination of the evaluated accessions. The information generated on the diversity of the accessions of $\mathrm{P}$. menziesii protected by the CNRG-INIFAP will allow the development of strategies for their conservation.

\section{Acknowledgment}

This study was funded by the National Forestry Commission (CONAFOR) through the project "Promotion and Operation of the Forest Genetic Resources Subsystem within the National Center for Genetic Resources (CNRG)" (No. SIGI: 11385232709). 


\section{References}

Álvarez, M.J.G., Alia, I.T., Colinas, M.T.L., Sahagún, J.C. (2007). Interspecific differences in postharvest quality on Mexican Christmas trees. Silvae Genetica, 56, 65-73.

Chekmeneva, Y., Tkachev, V. and Krasnov, V. (2019). Phenotypic variation of generative signs of different reproductive types of Pseudotsuga menziesii (Mirb.) Franco in urban environment (in the forest-steppe zone). IOP Conference Series: Earth and Environmental Science, 226: 012050.

Comisión Nacional Forestal (CONAFOR) (2018). Pseudotsuga menziesii. SIRE: CONAFOR-CONABIO. Paquetes tecnológicos. México. Recuperado de http://www.conafor.gob.mx:8080/documentos/ docs/13/991Pseudotsuga\%20menziesii.pdf.

Cruz-Nicolás, J., Vargas-Hernández, J.J., Ramírez-Vallejo, P. and López-Upton, J. (2011). Genetic diversity and differentiation of Pseudotsuga menziesii (mirb.) Franco populations in Mexico. Revista Fitotecnia Mexicana, 34(4), 233-240.

DOF (2015). Modificación del Anexo Normativo III, Lista de especies en riesgo de la Norma Oficial Mexicana NOM-059-SEMARNAT2010, Protección ambiental-Especies nativas de México de flora y fauna silvestres-Categorías de riesgo y especificaciones para su inclusión, exclusión o cambio-Lista de especies en riesgo, publicada el 30 de diciembre de 2010. Diario Oficial de la Federación. Recuperado de http://dof.gob.mx/nota_detalle.php?codigo $=542$ 0810\&fecha $=21 / 12 / 2015$.

Espitia Camacho, M., Cardona Ayala, C. y Araméndiz Tatis, H. (2017). Morfología y viabilidad de semillas de Bombacopsis quinata y Anacardium excelsum, Cultivos Tropicales, 38(4), 75-83.

Farjon, A. (2013). Pseudotsuga menziesii. The IUCN Red List of Threatened Species 2013: e.T42429A2979531. Recuperado de http://dx.doi.org/10.2305/IUCN.UK.20131.RLTS.T42429A2979531.en.

Ferreira, T. y Rasband, W. (2018). ImageJ 1.52b. National Institutes of Health. Recuperado de https://imagej.nih.gov/ij/docs/index.html.
Jaouadi, W., Naghmouchi, S., and Alsubeie, M. (2019). Should the silviculture of Aleppo pine (Pinus halepensis Mill.) stands in northern Africa be oriented towards wood or seed and cone production? Diagnosis and current potentiality. iForest Biogeosciences and Forestry, 12(3), 297-305.

Lima, L.F., Lima, Vila Nova de, R.G.L., Ferreira, A.G., Almeida Jr., E.B. and Silvia, C. (2017). Morphological characterization of fruit, seeds and seedlings of white-seal (Chrysophyllum rufum Mart. -Sapotaceae). Biota Neotropica, 17(4), e20170355.

Miniño Mejía, V.A., Paíno Perdomo, O., Rodríguez de Francisco, L.E., León, Y. y Paulino, L. (2014). Caracterización de la morfología de la semilla de Pinus occidentalis Swartz. Ciencia y Sociedad, 39(4), 777-801.

Montiel Castelán, P., Cortés-Cruz, M., Mendoza-Castillo, M.C., Cruz-Izquierdo, S., López-Upton, J., Sandoval Padilla, I. and Guerra de la Cruz, V. (2019). Diversity and genetic structure inferred with microsatellites in natural populations of Pseudotsuga menziesii (Mirb.) Franco (Pinaceae) in the central region of Mexico. Forests, 10(2), 101.

Peters, V. and Visscher, D. (2019). Seed availability does not ensure regeneration in Northern ecosystems of the endangered limber pine forests. Forests, 10(2), 146.

Pichardo González, J.M., Cruz Gutiérrez, E.J., Contreras Toledo, A.R., Cortés Aguilar, J., Cortés Cruz, M., Quintana Camargo, M., Torres García, E. y Gómez Reyes, L.A. (2018). La Colección Nacional de Recursos Genéticos Forestales en el CNRG-INIFAP. Publicación Especial Núm. 4. Centro Nacional de Recursos Genéticos. CIRPAC-INIFAP. Tepatitlán de Morelos, Jal. México. 189 páginas.

Ramírez-Sánchez, S.E., López-Upton, J., García de los Santos, G., Vargas-Hernández, J., Hernández-Livera, A. y Ayala-Garay, O.J. (2011). Variación morfológica de semillas de Taxus globosa Schltdl. provenientes de dos regiones geográficas de México. Revista Fitotecnia Mexicana, 34(2), 93-99. 
Reyes, H.V., Vargas, J.J.H., López, J.U., Vaquera, H.H. (2005). Variación morfológica y anatómica en poblaciones mexicanas de Pseudotsuga (Pinaceae). Acta Botánica Mexicana, 70, 47-67.

Rohlf, F.J. (2008). NTSYSpc: Numerical Taxonomy System, ver. 2.1. Exeter Publishing, Ltd.: Setauket, NY.

Sanhueza, A., Bourke, M., Grosse, H., Chacón, I. y Álvarez, P. (1998). Cultivo del Pino Oregón. Programa de Diversificación Forestal. Corporación Nacional Forestal. Chile. 106 p.

Ventura Ríos, A., López Upton, J., Vargas Hernández, J.J. y Guerra de la Cruz, V. (2010). Caracterización de Pseudotsuga menziesii (Mirb.) Franco en el centro de México. Implicaciones para su conservación. Revista Fitotecnia Mexicana, 33(2), 107-116.

Villaseñor, J.L. (2016). Checklist of the native vascular plants of Mexico. Revista Mexicana de Biodiversidad, 87, 559-902. 